肝障害を伴つた胆石症の外科手術の適応と限界

\begin{tabular}{|c|c|c|c|c|c|c|c|c|c|c|}
\hline \multicolumn{11}{|c|}{ 日本医科大学第 1 外科 } \\
\hline 樹 & & 勝 & 大 & 川 & 共 & 一 & 藤 & 島 & 義 & - \\
\hline 岡 & 正 & 智 & 恩 & 田 & 晶 & 彦 & 箱 & 崎 & & 敬 \\
\hline 水 & 淑 & 文 & 柴 & & & 積 & 埴 & 原 & 忠 & \\
\hline 山 & 雄 & 吉 & 遠 & 并 & 敬 & 三 & 柳 & & 郁 & 夫 \\
\hline 沢 & 隆 & 雄 & 山 & 口 & 健 & 次 & 代 & 田 & 明 & \\
\hline
\end{tabular}

\title{
SURGICAL THERAPEUTIC INDICATION AND LIMIT OF CHOLELITHIASIS WITH HEPATIC FUNCTIONAL DISTURBANCE
}

\author{
M. MIKI, G. FUJISHIMA, M. YOSHIOKA, M. ONDA, K. HAKOZAKI,
}

Y. SHIMIZU, T. SHIBA, T. HAIBARA, Y. MORIYAMA, K. TOOI,

I. YANAGI, T. TAKIZAWA, K. YAMAGUCHI, A. SHIROTA

Department of Surgery, Nippon Medical School, Tokyo, Japan.

1.はじめに

肝障害を伴つた疾患に対して，私ども外科医は積極的 に手術を敢行しなければならない機会にしばしば遭遇す るが，この肝障害が手術成績を左右する重要な一因子で あることは周知の通りである．とくに胆石症は，良性疾 患ではあるが, その発生, 病態生理が肝障害とは密接な 関係を有し, 胆道の機械的閉塞のみでは解決し得ない複 雑さがあるだけに，安易に取りくむと全く取りかえしの つかない重篤な結果を招く和それが多い。そこで教室の 症例を中心肝障害を伴つた胆石症の外科手術の適応と 限界について考察し，とくにその成因, 治療について不 明な点の多い肝腎症候群を中心にその知見を述べてみた い.

2. 胆石症の外科的治療成績の向上を阻害しているー 因子としての肝障害

䏣石症の手術成績は近年著しく向上しており，最近 15 年間の 1,235 例（有石例1087例, 無石例 148例) 中, 手 術による直接死亡はわずか炕14例（有石例12例, 無石例 2 例）で, 死亡率 $1.2 \%$ （有石例 $1.2 \%$, 無石例 1.4 \%)にすぎない，一般にも胆石症では，手術をしても危 険はないと評価されるまでとなりた昨今ではあるが，遠 隔成績をる考虑に入れ詳細に検討してみると，な括末解

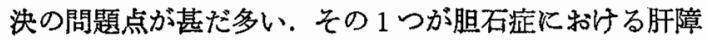

Fig. 1 胆石症患者の黄疾指数之手術成績 （昭和 32 年 47 年）

\begin{tabular}{|c|c|c|c|c|c|c|c|}
\hline \multirow{2}{*}{\multicolumn{2}{|c|}{ 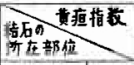 }} & 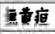 & 㵔在传 & 䫘 & 性重 & 症 & \multirow{4}{*}{$\frac{\text { 合 计 }}{854}$} \\
\hline & & $5 \mathrm{WF}$ & $6-15$ & \multicolumn{3}{|c|}{$|16-50| 5|-10| 10 \mid-105$} & \\
\hline \multirow{4}{*}{ 胆表緢石 } & \multirow{2}{*}{ 例教 } & \multirow{2}{*}{485} & \multirow{2}{*}{277} & \multicolumn{3}{|c|}{$92(10.7 \%)$} & \\
\hline & & & & 72 & 15 & 5 & \\
\hline & 死 E & 2 & 3 & 0 & 1 & 0 & 6 \\
\hline & ytth & $0.4 x$ & $1.1 \%$ & $0 \%$ & $7.1 \%$ & $0 \%$ & $0.7 x$ \\
\hline \multirow{4}{*}{ 胆管轺石 } & \multirow{2}{*}{ 列数 } & \multirow{2}{*}{66} & \multirow{2}{*}{78} & \multicolumn{3}{|c|}{$89(38.2 \%)$} & \multirow{2}{*}{233} \\
\hline & & & & 64 & 16 & 9 & \\
\hline & IE L & 0 & 1 & 3 & 2 & 0 & 6 \\
\hline & FLt+ & $0 \%$ & $1.3 \%$ & $4.7 x$ & $125 \%$ & $0 \%$ & $26 \%$ \\
\hline
\end{tabular}

害である，胆石症患者の黄疸は Fig. 1亿示す如く胆管 結石でも黄疾指数16以上の影性黄疾例は 233例中89例, $38.2 \%$ 亿すぎず，しかも黄疸指数 100 以上の高度黄疸例 はわずが9例であることからもわかるように，一般に その程度が軽く，から一過性のるのが比較的多いのは事 実である. そして手術成䋶との関係をみても黄疸が高度 となる程死亡率も高くなつてはいるが，高度黄疸例必ず しも死亡はしていない、しかしながら胆襄結石 854例中

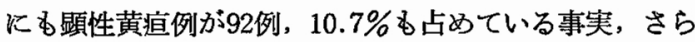
に, 黄疸を伴つた胆石症患者の術後の諸種肝機能の推移 を追跡してみると，Fig. 2k示す如く，外科的治療によ りその大多数は急速な改善が認められるが, 術後 1 ～ 3 年, さらに $4 \sim 7$ 年と長年月を経てもな特その低下を示 
Fig. 2 黄疾を伴つた胆石症患者の術後肝機能㭘查 成績

\begin{tabular}{|c|c|c|c|c|c|c|c|c|c|c|c|}
\hline \multicolumn{3}{|c|}{ tewate } & \begin{tabular}{|l|} 
MG \\
$16<$ \\
\end{tabular} & & & $\begin{array}{l}217 \\
128\end{array}$ & $\begin{array}{l}\pi T \\
48\end{array}$ & & $\begin{array}{l}\text { GPT } \\
35<\end{array}$ & $10 \mathrm{c}$ & 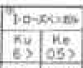 \\
\hline \multirow{3}{*}{ 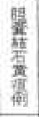 } & क्ष ज़ & 75 & $100 t$ & $9 y_{4} 4$ & 81: & 133 & 1389 & $95 \%$ & 5655 & 735: & $545 \%$ 818 \\
\hline & $\frac{16}{1-3 \frac{k}{4}}$ & 29 & 0 & $17 \%$ & 33.4 & 9 & 0 & 17: & 35 & $35:$ & $33: 33:$ \\
\hline & 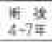 & 17 & 0 & 33 \% & 331 & A & & 0 & $\theta$ & $\theta$ & 334534 \\
\hline \multirow{3}{*}{ 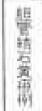 } & 4i & 81 & $100 \%$ & $9260^{\circ}$ & 553: & 2000 & $1775^{*}$ & 645:? & 812: & 8000 & $71 / 2: 857$ \\
\hline & 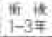 & 26 & 178 & $50:$ & $33 \%$ & 0. & a & $17:$ & $17:$ & $62:$ & $15 \div: 150$ \\
\hline & $\operatorname{lic}_{4 \rightarrow 74}$ & 13 & 0 & 85: & 5 : & 25 " & 0 & & $85^{\circ}$ & 0 & $25: 50$ \\
\hline
\end{tabular}

Fig. 3 術後10カ月以上経過した胆石症患者の ${ }^{131}$ I-Rose Bengal Test

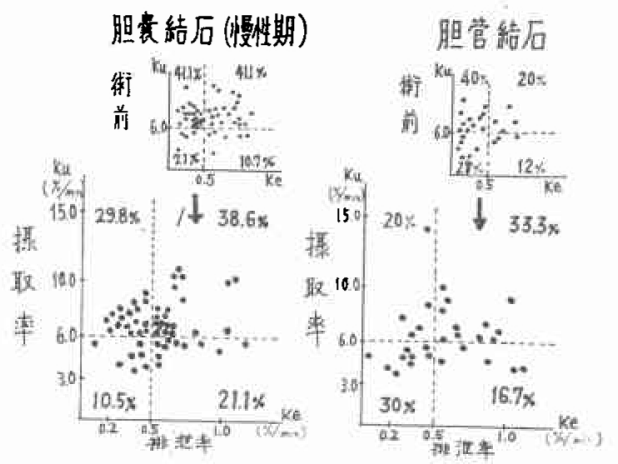

すものが，䏣囊，胆管結石ともに可なりのパーセントに 認められる事実は極めて注目されねばならないるのと考 壳ている.

いまその一として, 術後10カ月以上良好な経過をとつ た胆䧶結石55例，胆管結石 30例に対して行なつた ${ }^{131} \mathrm{I}$ Rose Bengal Test の成績をみると, Fig. 3にみられる如 く, 肝排泄能は術前に比し明らかに好転しているすのが 多いが, 摂取能は依然として低值を示し, 容易に改善し 難いものが少なくない.

このことは病理組織学的検索からも認められること で, 例觉ば Fig. 4（a）（b）は，70才, 男子, 買疽性 胆珡炎患者の胆震剔出術後 3 年を経過し, 精密検査のた め入院した際の朋生検の電顕像であるが, 杀粒体の減 少, 膨化, microbody の增加, 毛細胆管の拡大, microvilli の遊離減少などが依然として認められている. 因み に, この際の肝機能は黄㾝指数 7 倍, B S P $12.5 \%, \mathrm{G}$ O T 43, GP T 33, アルカリフォスファターゼ10.5, 総 コレステロール値 $230, \mathrm{~A} / \mathrm{G}$ 比1.05であつた. これら の事実は，胆石症患者にみられる肝障害が単に胆管の機 械的閉塞のみならず，グリンン氏鞘を中心とした肝内 胆管に和ける広範囲の炎症と，それに基因する組織学的 変化にも由来し，この肝障害はたと文結石を除去しても 容易に治癒し難いもので, 胆石症の外科的治療成績の向
Fig. 470 才, 男子, 壊疽性胆囊炎で, 胆軎剔出後 3 年目にお汀る肝生検電影像

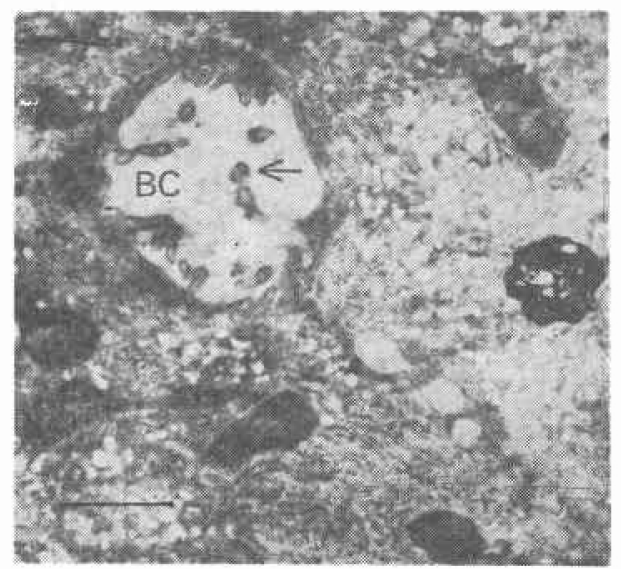

a) 毛細胆管の拡大 (BC), Microvilli の遊離減少 斑がめられる。（†）

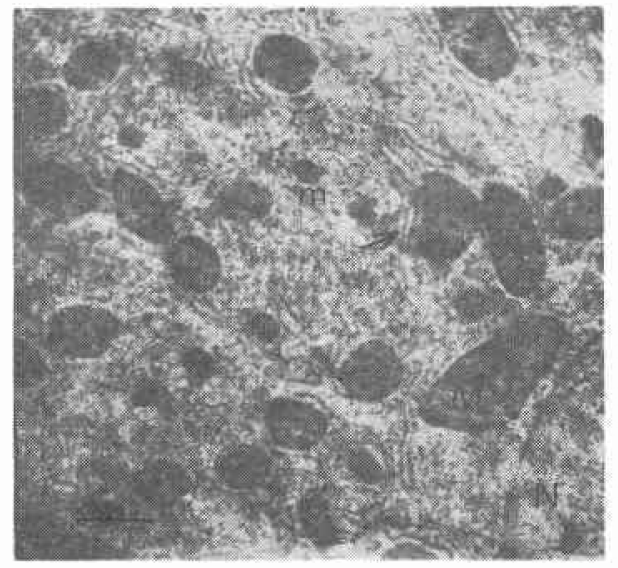

b) 系粒体 (M) の減少, 部分的には膨化を示すむ のがあり， microbody (m) の增加が認められる。 小胞体は系粒体に接して存在する。

上を阻害している重要な一因子になつていることを示す ものと考えている。

\section{3. 手術成績からみた適応と限界}

さきに述べた如く最近15年間の胆石症 1,235 例のう ち，手術による直接死亡は14例であるが，その死因を検 討してみると，心循環不全によるものが 6 例で最も多 い.このことに関してはすでに松倉"，代田 ${ }^{2}$ がその詳 細を報告しており，その原因として高令者に対する手術 の増加も一因ではあるが，胆石症にお忷る心電図異常所 見，とくに S T，Tなどの異常が18.5\%にも認められる ことに注目，これらが術後 $81.8 \%$ に改善されることなど の事実から胆石症と冠不全との間に密接な因果関係が存 していることを立証, 注意を喚起している. 同様の傾向 
は Glenn ${ }^{3)}$ む指摘しているところで，1932～1950年の良 性胆道疾患 3439 例中63例が死亡し, 死亡率 $18 \%$, その死 因としては肝の感染, 硬変あるいは壊死などの朋不全

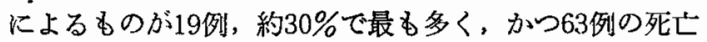
例中52例に胆汁性肝硬変の所見を認めているが，1950 1962年の 2358 例では39例が死亡し $1.7 \%$ 死亡率で, そ の死因の第一は Cardiovascularrenal disease によるもの で，23例，59\%を占めていたと報告している.

poor risk の高令者手術がますます多くなつている現 在, たしかにこのことは重要であるが，心循環不全に よる 6 例を除く 8 例の死因をみると，急性腎不全, 胆血 症, 肝膿瘍, 術後出血, 脳出血各 1 例であつて, 脳出血 の1例を除汭いずれも肝障害と極めて密接な関係を有

Fig. 5 胆石症 1221 例の術後遠隔成績（死亡例の死 因）（昭和32年～47年）

\begin{tabular}{|c|c|c|c|c|c|c|c|}
\hline \multirow{2}{*}{\multicolumn{2}{|c|}{ 死 }} & \multirow{2}{*}{ 夘数 } & \multicolumn{5}{|c|}{ 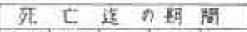 } \\
\hline & & & 17L4h & $11-37$ & $3-57$ & 5qut & $F$ 개 \\
\hline 悬 & 胆道癌 & 11 & 6 & 0 & 3 & 2 & 0 \\
\hline 道 & 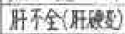 & 7 & 2 & 1 & 2 & 2 & 0 \\
\hline W & 鲁性些不全 & 3 & 2 & 1 & 0 & 0 & 0 \\
\hline 离 & 消化菅出血 & 3 & 1 & 0 & 1 & 1 & 0 \\
\hline 传 & 霆 血庭 & 2 & 2 & 0 & 0 & 0 & 0 \\
\hline ह & 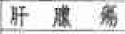 & 2 & 1 & 0 & 0 & 1 & 0 \\
\hline क) & 小 部 & 28 & 14 & 2 & 6 & 6 & 0 \\
\hline & a) 12 & 37 & 11 & 10 & 2 & 10 & 4 \\
\hline & 合 計 & 65 & 25 & 12 & 8 & 16 & 4 \\
\hline
\end{tabular}

する合併症ばかりである，さらにまた，耐術者1221例の 遠隔成績を検らべたところ，退院後死亡が確認されたも のが65例であるが，その死因を検討してみると，Fig. 5 に示す如く胆道系に直接間接関係のあると思われるもの が28例，実に43\%を占めている，このうち胆道癌による ものが11例で最も多く, 次いで胆汁性肝硬変など肝不全 により死亡したものが 7例, 急性腎不全, 消化管出血に よるものが各 3 例, 胆道閉塞による胆血症, 肝膿瘍に上 るむのが各 2 例で, 直接死亡例と同様に肝障害と密接な 関係のあるすのが多かつたことは特に注目すべき点であ ると思われる。

これらはいずれも手術の適応と限界を示唆するもので あるが，それでは臨床上どの程度の肝障害があつたとき は手術の限界であるか具体的にその闘值を示せと云われ ると,これは甚だ困難である. 何故ならば，上述の死亡 例を検討してみると, 肝障害の程度そのるのは, 黄疸の 程度にしても悪性胆道膵疾患の如く高度のものはむしろ 少なく, 多くは黄㾝指数 50 ～ 80 程度の中等度黄疸であ る. にも拘らず胆辜乃至胆道の急性炎症性病変が極めて 高度の場合には, 手術侵襲の大小火かかわりなく全く不 測の事態が突如起り得るからである.

その最も典型的なものは, 術後突如として発来する
急性腎不全である，この合併症は，これを術前に予知す ることは甚だ困難であるばかりでなく，ひとたび発来す ると全くと申してょいくらい，之の良策を見い出し得な いのが現状であるので, 肝障害時における手術の適応と 限界を探る一材料として, 以下本合併症に関する臨床的 ならびに実騇的研究成績を中心に述べてみたい。

4. 術後の急性腎不全の発来機構について

胆石症の術後に急性腎不全の症状を呈して死亡した 5 例の臨床像を再検討してみると，Fig. 6 亿示寸如くで, いくつかの点で特徴的な共通点が見い出される. まず第 1 は手術時所見として，5例中 4 例までが急性壊疽性胆 霆炎乃至穿孔性胆軎炎で胆道系の急性炎所見が極めて高

Fig. 6 胆石症手術後急性腎不全により死亡した 5 例（昭和 32 年 47 年）

\begin{tabular}{|c|c|c|c|c|c|c|c|}
\hline & 氏名 & 手隺族断 & 手解々式 & M.G. & $A L p$. & 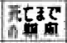 & 情 \\
\hline 1 & 世o & 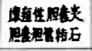 & 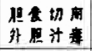 & $4 x$ & 35.5 & $2 \mathrm{~B}$ & 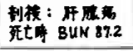 \\
\hline 2 & $\begin{array}{cc}\text { 原 } & 0 \\
4 & 0\end{array}$ & 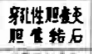 & 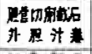 & $72^{x}$ & 23.0 & 478 & 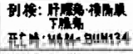 \\
\hline 3 & $\begin{array}{l}700 \\
8249\end{array}$ & 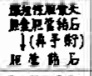 & 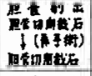 & 5. & 173 & $\begin{array}{r}4 t^{4} \\
4 \\
128 \\
12\end{array}$ & 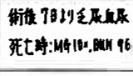 \\
\hline & 乾。 & 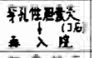 & 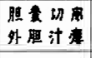 & $40 \%$ & 378 & 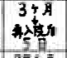 & 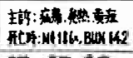 \\
\hline & $\underset{\substack{t \\
\Delta \leq y \leq t}}{0}$ & 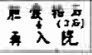 & 胆者制出 & $40 x$ & 30.0 & 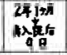 & 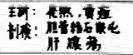 \\
\hline
\end{tabular}

度なすのが多い，第 2 に胆管結石例が多い, 症例 (1) （2）はもちろん，再入院して死亡した 3 例む，そのう ち2 例（症例 (3) (5)) は, 再手術および剖検により それぞれ胆管に批りる遺残乃至再発結石の存在を確認 している. 第 3 に黄疸を呈したものは（症例 $2 ， 4$ 。 5）3 例であるが黄瘨指数はそれぞれ72，40，40倍で必 ずしも高度とは云兄ないままたこれらの症例は勿論。 無黄瘨例 2 例（症例 1,3 ）発熱, 白血球增多, アル カリフォスファターゼ値の上昇がみられ, 細胆管炎乃至 肝膿湯をを疑わしめる検査所見を示していた．第4亿， 剖検し得た 3 例（症例 $1 ， 2 ， 5$ ）はいずれる肝膿瘍。 横隔膜下膿場が認められた. 第 5 に, 手術侵襲乞のるの が乏尿の発来関与したと考穴られるものは 3 例（症例 $1 ， 2 ， 3$ ) であるが, 死亡までの期間をみると, 症例 1 の如く術後 2 日の如き早期のものもあれば，12日乃至 47日と可なりの日数を経ているものもあり一定していな い.

この死亡例の検討からすると，乏尿を主訴とした急性 腎不全は, 黄㡺乃至肝障害のあるものに発来し易いこと は事実であるが，黄㾝乃至肝障害が高度であれば起ると いうものではないということになる.

事実臨床上肝腎症候群の発来を予知することはたと 
Fig. 7 胆石症患者の黄疸指数と婜機能（P S P 值）

\begin{tabular}{|c|c|c|c|c|c|c|c|c|c|c|}
\hline \multirow{3}{*}{ PSP } & \multicolumn{5}{|c|}{ 䏣 结 石 } & \multicolumn{5}{|c|}{ 䏣 草 石 } \\
\hline & \multirow{2}{*}{ 例唓 } & \multicolumn{2}{|c|}{ 15A-25\%以下 } & \multicolumn{2}{|c|}{ Total 70 SLLT } & \multirow{2}{*}{ 例毁 } & \multicolumn{2}{|c|}{ 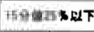 } & \multicolumn{2}{|c|}{ Tow 70S, } \\
\hline & & 的勡 & $\%$ & 约数 & $\%$ & & (6) & $\%$ & at & $\%$ \\
\hline-15 & 81 & 33 & 40.7 & 42 & 51.8 & 24 & 6 & 25.0 & 13 & 54.1 \\
\hline $16 \sim 50$ & 5 & 2 & 40.0 & 3 & 60.0 & 7 & 5 & 71.4 & 6 & 85.7 \\
\hline $51 \sim$ & 3 & 3 & 100 & 2 & 66.6 & 3 & 0 & 0 & 1 & 33.3 \\
\hline If & 90 & 38 & 42.2 & 47 & 52.2 & 34 & II & 32 & 19 & 55.8 \\
\hline
\end{tabular}

Fig. 8 閉塞性黄疸剖検67例の肝・腎組織像の比䡈 検剖

肝病型

\begin{tabular}{|c|c|c|}
\hline $\begin{array}{l}\text { 口心性黄痹軽 } \\
(+)^{2} \\
\text { (29例) }\end{array}$ & $\begin{array}{c}\text { 中心性黄痹中 } \\
\text { 等度(茾) } \\
\text { (14例) }\end{array}$ & $\begin{array}{l}\text { 中心性異病渚 } \\
\text { 明 }(\text { 册) } \\
(24 \text { 例 })\end{array}$ \\
\hline
\end{tabular}

腎病型

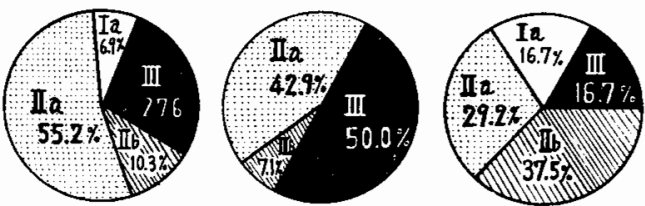

\begin{tabular}{|c|c|c|c|c|c|}
\hline \multicolumn{2}{|c|}{ 珡病型 } & $\begin{array}{l}\text { 間質浮腫 } \\
\text { ・線維化 }\end{array}$ & $\begin{array}{l}\text { 尿細管 } \\
\text { 拻 張 }\end{array}$ & $\begin{array}{l}\text { 胆计色素 } \\
\text { 再吸驱 }\end{array}$ & $\begin{array}{l}\text { 胆计色素 } \\
\text { の存在寸 } \\
\text { る尿乃柱 }\end{array}$ \\
\hline \multirow{2}{*}{ I } & a & \pm & \pm & + & + \\
\hline & b & - & - & 冊 & 册 \\
\hline \multirow{2}{*}{ I] } & a & + & + & H & + \\
\hline & $\bar{b}$ & H & $H$ & 冊 & H \\
\hline \multicolumn{2}{|c|}{ III } & WH & W & $+\sim$ & $+\sim$ \\
\hline
\end{tabular}

え術前にクリアランステスト， P S P， あるいは ${ }^{131} I-$ Hippuran による Renogram などによつて詳細に腎機能 を検索して居つても極めて困難である．Fig.7は黄疾の 程度と竪機能 P S P 值との関連性を追求したものである が, 両者は必ずしも一致していない, 教室の箱崎せはこの 点に関し, 閉塞珄黄疸により死亡した剖検例67例を材料 としてPAM染色矢島変法によつて肝和よび腎の病理組 織学的検索を行なつているが，その成績によると腎の病 変としては, 近位尿細管のみならず, 遠位尿細管にも胆 汁色素の再吸収が認められ，その程度に応じて尿細管上 皮の腫大，膨化がみられ，さらに加らるに間質の浮腫， 線維化拉よび尿細管拡張などの所見が種々の程度に見ら れて, いわゆる lowernephron nephrosis 型変化之胆汁色 素性障害の加味された像を呈している. いま先の程度に 応じて 3 型に分ち, 一方肝の病型を中心性黄疸の程度に 応じて（+）（H）（卅）の3 型に分つて両者の相互関 係を検討してみると，Fig. 8に示すように，肝黄㾝の程
Fig. 9 肝腎症候群を呈した閉塞性黄病患者25例の 主要剖㭘所見

\begin{tabular}{|c|c|c|}
\hline 主要剖検所見 & $\begin{array}{l}\text { 胆厉莚 } \\
14 \text { 例 }\end{array}$ & $\begin{array}{c}\text { 胆道癌 } \\
\text { | 例 }\end{array}$ \\
\hline 境㾝性胆秦炎 & 4 & 2 \\
\hline 肝 腿 痬 & 5 & 3 \\
\hline 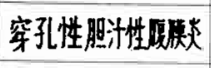 & 3 & 0 \\
\hline 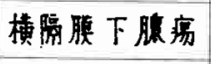 & 3 & 1 \\
\hline 消化管出血 & 4 & 3 \\
\hline 肝内門脈血栓 & 2 & 0 \\
\hline 脏胫内出血 & 1 & 1 \\
\hline クモ膜下出血 & 0 & 1 \\
\hline
\end{tabular}

度と腎病型の重篤度とは必ずしも平行していない，そこ でさらに臨床上急性腎不全症候を呈して死亡した25例の 剖検所見を詳細に検討してみたところ，Fig.9に示すよ らに，胆石症14例では全例に，胆道癌11例では 8 例に壊 疽性胆露炎, 肝膿瘍, 穿孔性胆汁性腹膜炎, 横隔膜下膿 瘍, 消化管出血といつた重篤な合併症ないし続発症が認 められた。 またこの25例のらち胆石症 5 例, 胆道癌 4 例, 計 9 例が手術を受けているが，その術式を検べてみ ると, 外胆汁瘦造設, 試験開腹術など極めて軽度な手術 侵襲によつても起きているのが注目された。

以上の成績から，いわゆる肝腎症候群と云われるもの は, 単に閉塞性黄疸が高度であるから起るといらもので はなく、たと共疸が軽度であつても, 胆道系を中心と した资症とか, 出血などの重篤な合併症乃至続発症があ つた場合には，わずかな外科的手術侵襲が加わつても発 生し易いと考㝋られる.

そこで, 次にこれら明らかにする1つの手段として， 一群の実験的研究を行なつた. 犬に実験的胆道閉塞をつ くり，まず腎血浆流量と糸球体濾過值の変動をみると，

Fig. 10K示す如く，胆管結禁後 5 7 日飞約 20\%前後

Fig. 10 胆道閉塞および実験的胆罴炎犬における 腎機能

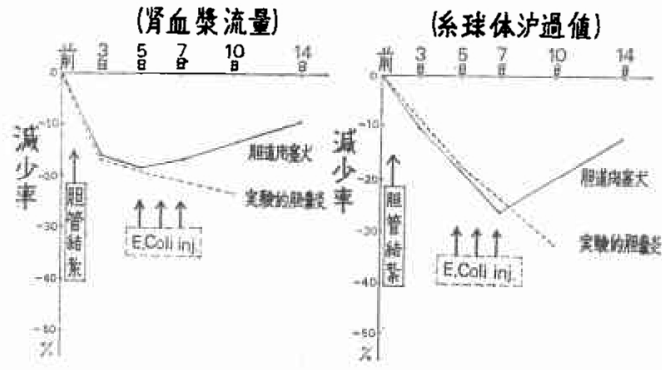


Fig. 11 胆道閉塞および実験的胆裹焱家鬼にお ける血清抗利尿物質（A D S) の消長

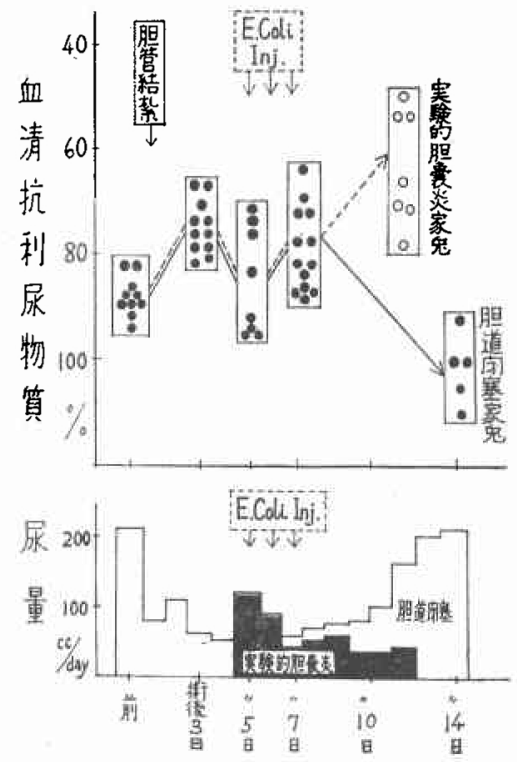

Fig. 12 胆道閉塞および実験的胆囊炎犬におけ る流血中フェリチンの変動

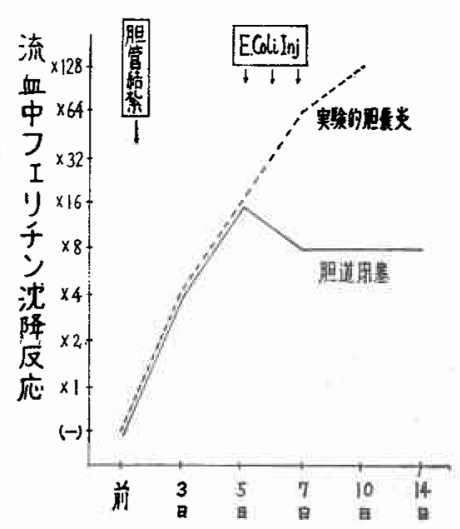

の減少率を示し，以後次第に旧に復するのに反し，胆 管結禁後5日前後に大腸菌 Escherichia Coli $\mathrm{O}_{26}$ を門 脈内に注入して䏣道感染を起さしぬ，実験的壊疽珄胆 囊炎を起すと，点線で示す如くさらに著明な減小がみら れる，次にこれと同様の実験法によつて血清抗利尿物質 （AＤＳ）の変動をみると, Fig. 11に示す如く感染群に おいては対照群にくらべて, その増量が極めて顕著であ つて，かつ著しく乏尿が招来された．これに対して，肝 に和ける A D S 非活性化能は両群の間に差異は認められ なからた。ささらに乏尿と密接な関係がある血清 Ferritin の消長を追求してみると，Fig. 12に示す如く，胆道閉
Fig. 13 胆管結揫後 5 日目に大腸菌 coli $\mathrm{O}_{26}$ を門 脈内に注入, 実験的㙗㡺性胆囊炎を起さ乙 めた家鬼の10日目における腎組織像

a) 腎光顕像

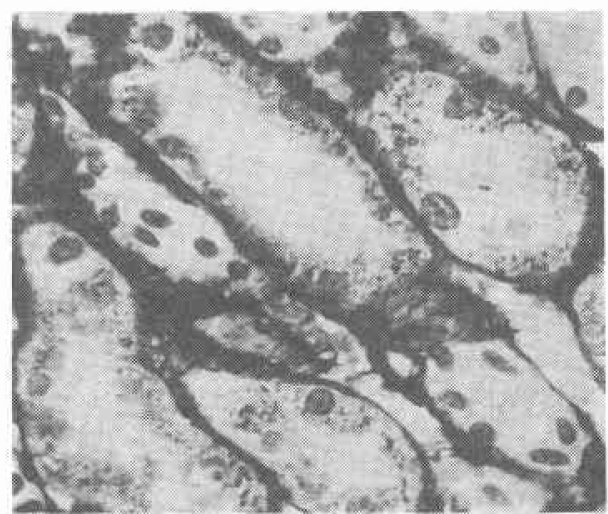

P A M染色， $200 \times$ 尿細上皮の腫大，膨化が顕著で， 上皮内に P A M陽性顆粒が豊富に認められる。

b）腎電䫓像（系粒体）

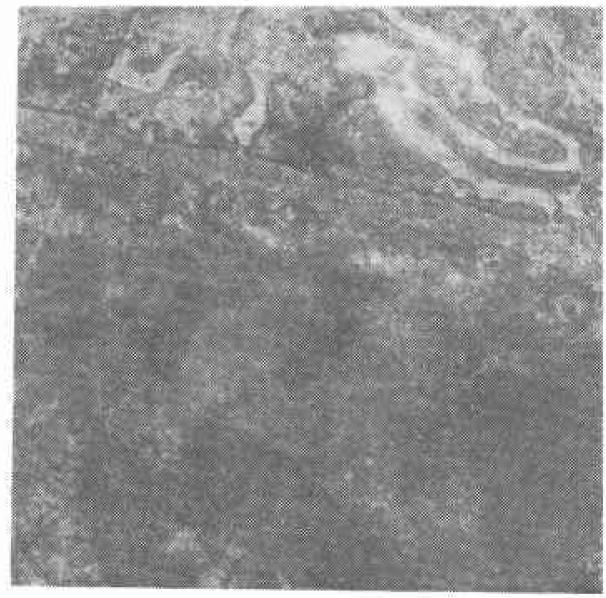

内皮細胞の著しい增生と, 基底膜の膨化, 足突起の 膨化が著しい

塞群では 5 日頃まで著しい増量を示し，以後減少する のに反し, 感染群ではさらに著しい增量を示している。 一方肝，腎飞和ける病理組織学的変化をみると，胆管結 紮後 5 日目に执ける变化が最す著明であつて, 肝細胞索 の著しい膨化, 細胞質の好酸性壊死, Sinus の拡張なと゚が 目立ち，P AM陽性顆粒が細胞質に滈慢性に認められ， 腎においても糸球体の細胞成分の堌加, P A M陽性成分 の増加が認められ, 電顕像によつて子, 系球体の内皮細 胞の変性, 基底膜の膨化, 足突起の融合, 脱落などの変 性所見が極めて強い。これらの変化は単なる胆道閉塞で は通常10日乃至 2 週間を経過すると寧乃次第に修復され 
る傾向を示してゆくが，これに反し実験的胆䧶炎を起さ しめた感染群では肝間質に広範な円形細胞浸潤を認める ようになり, 肝細胞索の変化も胆道閉塞群の極期におけ るよりもむしろ強くなつて拈り，腎においても Fig. 13

（a）の如く尿細管上皮の踵大，膨化が顥著となると ともに，上皮内に P AM陽性の細胞粒が豊富に認められ るよらになり，系球体に扎いても， Fig. 13 (b) の電 顕像にみられる如く，内皮細胞の著しい増生と基底膜の 膨化，さらに足突起の膨化などの著しい変化が浔められ る。

以上の臨休的奏験的成績から，いわゆる肝腎症候群の 発来は肝黄疸や肝障害の存する場合に惹起され易いのは 事実であるが，必らずしもその程度と平行せず，なんら かの手術侵襲や胆道感染を主とした重篤な合併症ないし 継発症を伴つた場合に発生し易く，この際腎には主とし $\tau$ lower nephron nephrosis 様変化と胆汁色素性障害の 加味された病変が認められ, 血清 A D S, 流血中 Ferritin の増量などと相俟つて著しい腎機能の低下が招来される と考㝋ている．著者らと同様，Martini ${ }^{5)}$, Hinchey ${ }^{6)}$, 中 野" 万年閉塞性黄疸時の急性腎不全の発来に細菌感染の 意義を重視し，とくに Hinchey ${ }^{6)}$ は, acute obstructive suppurative cholangitis と呼ばれる一群の疾患24例を検 索し，その原因の大部分は胆道結石あるいは術後の良性 胆道狭窄で23例を占め，その5ち8例が急性腎不全によ り死亡していることを指摘している.しかしながら,さら に進んで肝障害に胆道感染が加わつた場合に，何故腎障 害が発来し易いのか，その機構に関してはなお不明の点 が多い，今日最も考えられることは，エンドトキシンの 役割であり, 中野》もこの点を想定して, 黄症犬や非黄 疸犬に拈けるエンドトキシンショック時の腎血流を出血 ショックを対照として比較検討し, 出血性ショックの際 には脱血によつて腎血流は零となつても，還血により血 圧，心拍出量を回復させると腎血流も平行して脱血直前 に戻り, 腎血管抵抗, 総末梢抵抗回復するのに反し, エンドトキシンショックでは輸液により血圧や心拍出量 が回復し，総末梢抵抗が低下した時期でも，これに平行 して腎血流量は回復しにくく，珡血管抵抗は高く維持さ れること，とくに黄㾝犬のエンドトキシンショックの際 にはこの傾向が一層著明であるとその 成績を報告して
いる.しかしなか゚ら，上述 Hinchey ${ }^{6)} か ゙$ 述べた acute obstructive suppurative cholangitis の如き症例の時に, 果してエンドトキシンが血中に流出してくるものなの か，若し出るとしても不可逆的な腎障害を起すに足るる のであるのか否か，エンドトキシンと ADS, Ferritin, その他われわれがェンドトキシン・ショック特の有力な 'chemical mediator として立証しているキニン系 ${ }^{8)}$ など 乏尿機構に関与した因子との相互関係はどらであるのか などの諸問題が末解決のままのこされており，いわゆる 肝腎症候群の発来機構の解明はな尔将来の梌討に俟つる のが多い。

\section{5. おわりに}

以上胆石症を中心に, 肝障害と手術成績について述べ たが，単に黄疸の程度のみが外科手術の適応と限界を示 寸ものではなく，肝腎症候群症例においてる見られる如 く,これと作存した極めて難治の炎症性病変の関与が重 要なキーポイントを握つているものと考えられ，今後の 研究に俟たねぱならぬものが多々存するすのと考える.

\section{文献}

1）松食三郎：胆石症, 臨床外科全書, 第 4 巻（II） $323 \sim 427$, 金原出版, 昭和 41 年.

2) 代田明郎：胆石症の乎術適応決定上の問題点, 手術, 25, 5, 590 598, 1972.

3) F. Glenn and McSherry: Ethiological factors in fatal complications following operations upon the biliary tract. Ann. Surg., 157, 5, $695,1963$.

4) 箱崎 敬：閉塞性黄病の臨床的並びに病理学的 研究, 特にPAM染色による胆汁性ネフローゼ の再検討：日外誌，68，7，978～999，1967.

5) Martini, G.A.: Das sogenante hepatorenale Syndrom, Gastroenterologia 104, 117, 1965.

6) Hinchey, E.J., Couper, C.E.: Acute obstructive suppurative cholangitis. Am. J. Surg., $117,62-68,1969$.

7) 中野春雄 : 閉塞性黄㾝患者の腎障害に関する臨 床的並びに基礎的研究，一エンドトキシンショ ックとの関連一, 日外会誌, 72, 7, 904, 1971.

8) 代田明郎：外科臨床におけるエンドトキンン・ ショックの発来機構についてーとくにイレウス 時のキニン系の動態を中心として一, 外科治療, $29,3,241,1973$. 